\title{
Modelling and Simulation of Light and Temperature Efficient Interdigitated Back- Surface-Contact Solar Cell with 28.81\% Efficiency Rate
}

This paper was downloaded from TechRxiv (https://www.techrxiv.org).

\section{LICENSE}

$\mathrm{CCO}$

SUBMISSION DATE / POSTED DATE

$18-11-2021 / 07-01-2022$

\section{CITATION}

RAHMAN, MD MAHFUZUR (2022): Modelling and Simulation of Light and Temperature Efficient Interdigitated Back- Surface-Contact Solar Cell with 28.81\% Efficiency Rate. TechRxiv. Preprint. https://doi.org/10.36227/techrxiv.17038943.v1

$\mathrm{DOI}$ 


\section{Modelling and Simulation of Light and Temperature Efficient Interdigitated Back- Surface-Contact Solar Cell with 28.81\% Efficiency Rate}

\author{
Dr. Amirjan Bin Nawabjan \\ Center of Electrical Energy System \\ Department of Nano-Micro System Engineering \\ University of Technology Malaysia \\ Johor 81310, Malaysia \\ amirjan@utm.my
}

\author{
Md Mahfuzur Rahman \\ Department of Nano-Micro System Engineering \\ University of Technology Malaysia \\ Johor 81310, Malaysia \\ mrmd4@graduate.utm.my
}

\begin{abstract}
Back-contact solar cells improve optical properties by moving all electrically conducting parts to the back of the cell. The cell's structure allows silicon solar cells to surpass the $25 \%$ efficiency barrier and interdigitated solar cells are now the most efficient. In this work, the fabrication of a light efficient and temperature resistant interdigitated back contact (IBC) solar cell is investigated. This form of solar cell differs from conventional solar cell in that the electrodes are located at the back of the cell, eliminating the need for grids on the top, allowing the full surface area of the cell to receive sunlight, resulting in increased efficiency. In this project, we will use SILVACO TCAD, an optoelectronic device simulator, to construct a very thin solar cell with dimensions of $100 x 250 u m$ in 2D Luminous. The influence of sunlight intensity and atmospheric temperature on solar cell output power is highly essential and it has been explored in this work. The cell's optimum performance with $150 \mathrm{um}$ bulk thickness provides $28.81 \%$ efficiency with $\mathbf{8 7 . 6 8 \%}$ fill factor rate making it very thin, flexible and resilient providing diverse operational capabilities.
\end{abstract}

Keywords - interdigitated, shading, recombination loss, incident-plane, drift-diffusion, Luminous, SILVACO

\section{INTRODUCTION}

Energy alternatives other than burning fossil fuels are desperately needed in the face of escalating climate change challenges. Sunlight is the most prominent source of accessible energy. Solar cells that use photovoltaic technology transform sunlight into power without harming the environment. While the usage of solar energy is growing at an exponential rate, continual technological and structural improvement, as well as interfaces between materials and the best architecture, are required for efficient photovoltaic devices.

Metal connections that connect the semiconductor material to an external load, determine the efficiency of a solar cell. In a traditional solar cell, connections are formed in a grid pattern at the top of the cell [1]. Shading occurs when the grid's covered areas reflect sunlight, lowering a solar cell's effectiveness by $8 \%$ to $10 \%$ [2]. The grid also introduces losses due to the grid conductor's resistance. Although a thicker grid reduces electricity losses, it also increases shading. Making the connections narrower to prevent shadowing also raises grid resistance, leading in higher resistive losses. The IBC structure solves this optimization problem by balancing these two losses, resulting in the highest possible power production. The efficiency of the IBC cell increases by up to $25 \%[3,4,5]$ and the short circuit current is larger than that of traditional solar cells due to the lack of front-surface grid connections (Figure 01).

A)

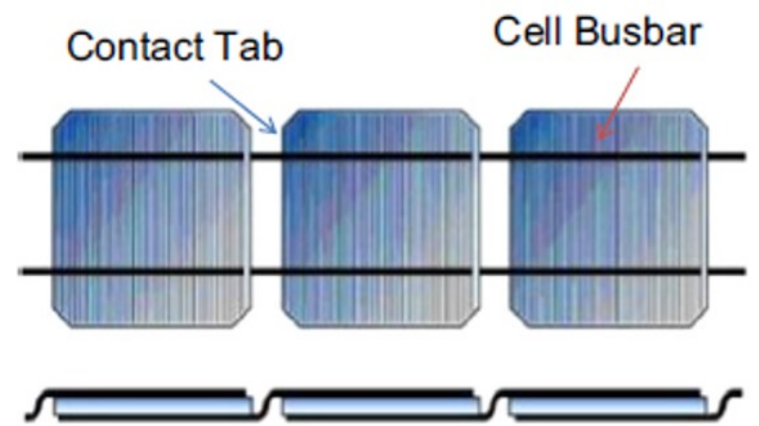

B)

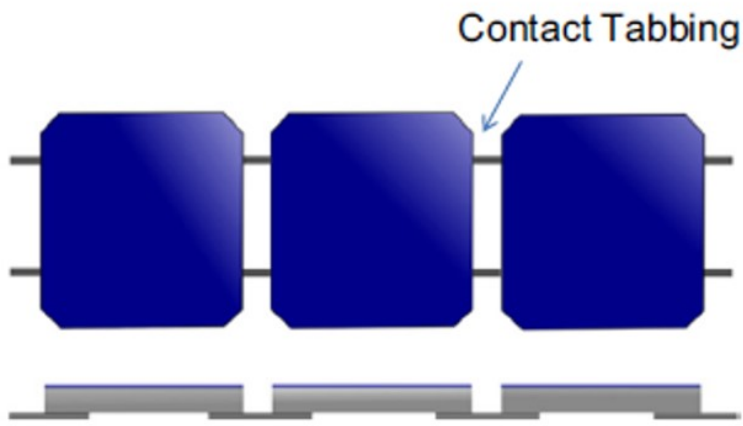

Figure 01: (A) Connections of Electrodes in Conventional Solar Cell on Front Surface. (B) IBC Cell Contacts at The Back on The Cell Surface Eliminating Front Surface Grid Shading Effect [6]

\section{WORKING PHYSICS OF IBC SOLAR CELL}

The PN junction serves as the foundation for solar cell production. When photons from sunshine strike the electrons in $\mathrm{p}$ and $\mathrm{n}$ semiconductor materials that are arranged flat on top of each other and exposed to sunlight, 
enough energy is transferred to release the electrons (Figure 02). The electrons can flow through a channel created by connecting metal contacts to the $\mathrm{n}$ and $\mathrm{p}$ materials. Even if the photon enters the substance, there is no guarantee that it will liberate an electron. The photon must collide with an electron in order to transfer its energy to it. When a photon successfully frees an electron, it leaves a hole in the location where the electron was [7]. The created electron hole pair must be separated and transported to their appropriate electrical connections. These pairings form at various depths within the semiconductor material. As they approach the contacts, they come into contact with other holes and electrons, perhaps causing them to recombine and be lost.

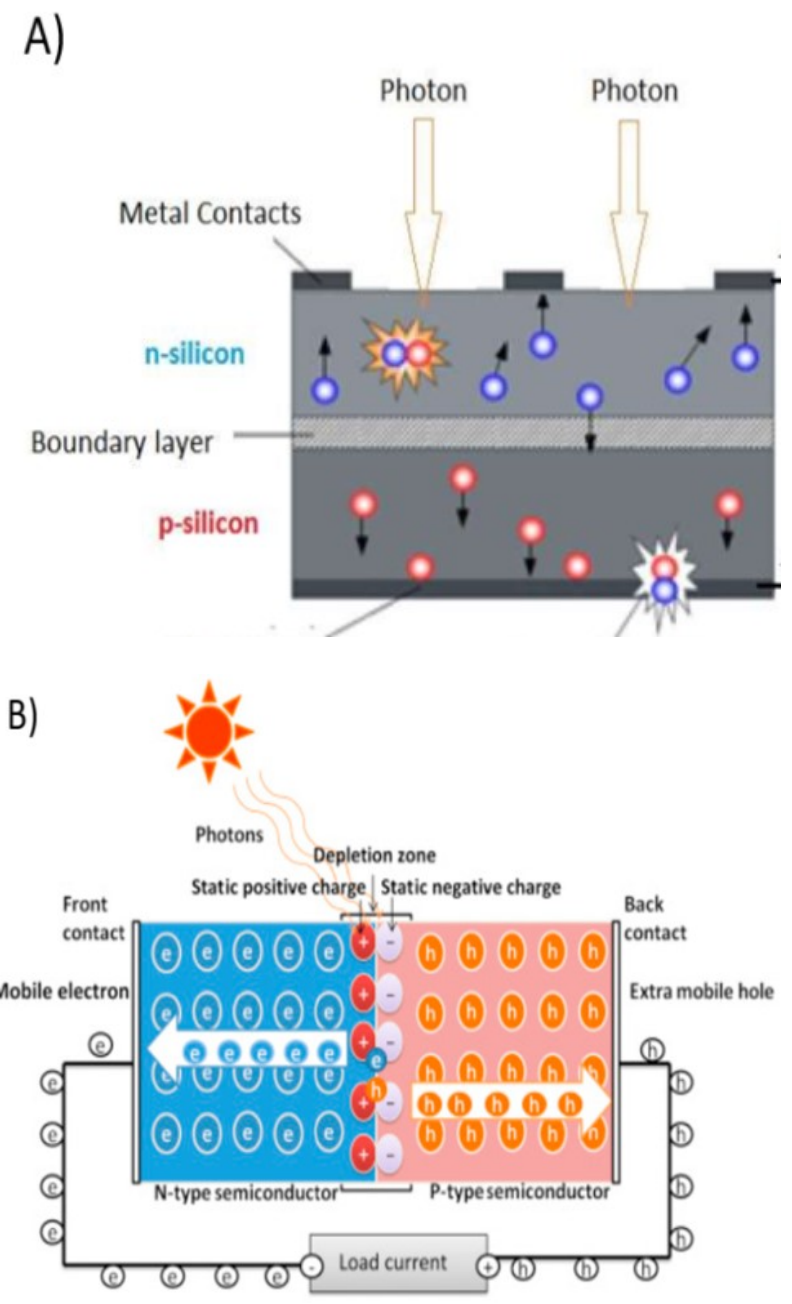

Figure 02: (A) Photons Absorption in Depletion Region Generating Electron-Hole Pair. (B) PN Junction- Interface Between The P-Type And N-Type Material. The Electrons Start Moving from One Region to Another When the Light Fall on The Junction $[8,9]$

\section{A. Equilibrium Between Absolute Crystal and Impurities for Optimal IBC Cell Efficiency}

Recombination losses are increased by imperfect crystal structures and impurities in the semiconductor material. Recombination losses can be reduced by reducing the bulk thickness. However, it lowers the likelihood of a photon generating an electron-hole pair. Heat is generated by the electron-hole pair generation process, which is then transported to the solar cell. Excess heat causes lattice vibrations, which interfere with charge transport and impair efficiency; yet, the higher energy photon still forms an electron-hole pair. Multiple junctions with varying band energies are created by layering different combinations of materials, enhancing the cell's efficiency $[7,10]$.

\section{INTERDIGITATED BACK CONTACT (IBC) TECHNOLOGY}

\section{A. Structure of Proposed IBC Cell for $26 \%$ Efficiency}

The $\mathrm{p}$ and $\mathrm{n}$ materials are positioned side by side on the bottom of the interdigitated back contact solar cell, with the electrodes connected to them in an interdigitated pattern [13]. The electrodes are made at the bottom of the cell, therefore there is no need for a grid on top (Figure 03). The removal of the grid on the top surface area eliminates losses due to shading of the semiconductor material, resulting in a $10 \%$ increase in the quantity of sunlight captured. For conventional cells, the shading effect can be decreased by reducing wire size at the expense of increased resistive losses. The grid wires may be made considerably larger, lowering both series resistance and resistive losses, because the electrodes are on the bottom of the IBC solar cell and shading is not an issue $[10,4]$.

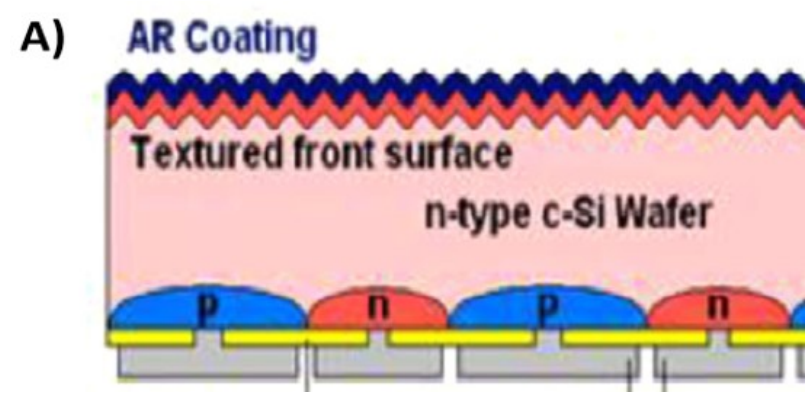

B)

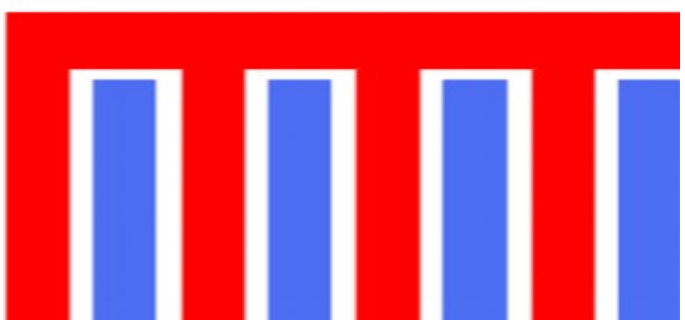




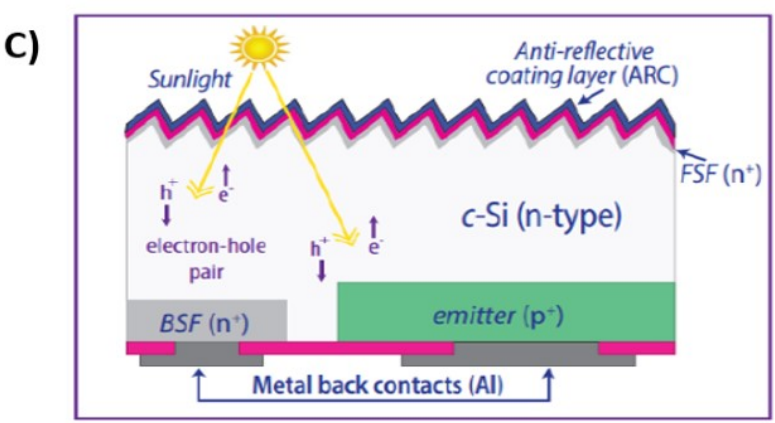

Figure 03: (A) Interdigitated Back Contact Solar Cell Structure with AR Coating and Contacts at The Bottom of The Cell. (B) An Interdigitated Electrode Pattern (Current Collecting Electrodes) Where Red Color P-Type Contact and Blue Color N-Type Contact. (C) Working Physics of AR Coating IBC Solar Cell $[11,12,10]$

\section{B. Investigation of Flexibility on Silicon Based Solar Cell}

Semiconductor material is used to make solar cells. The addition of thermal or optical energy can considerably enhance the number of electrons accessible for conduction in semiconductors. When sunlight strikes this material, electron hole pairs are created, which can subsequently be collected and used to generate power. Silicon is the most common semiconductor material used in solar cells [7,9]. A thin film solar cell composed of Cadmium Telluride is one of the alternatives. Cadmium Telluride cells are exceptionally bendable and long-lasting. Telluride, on the other hand, is a scarce substance that could provide an issue in large-scale production. Cadmium is also poisonous, which raises health and environmental problems when it is manufactured and used [2]. As a result, we shall explore silicon-based IBC solar cells in this paper work, taking economic and other factors in consideration.

\section{Surface Texturing with $40^{\circ}$ Angle Incident Pane and Anti-Reflective Coating}

The manufacturing process is simplified because the electrodes are at the bottom of the surface, needing no grid on the top of the cell. Texturing the top of the solar cell surface reduces the quantity of reflected light, resulting in a nearly 180-degree angle between the reflected sunlight and the adjacent surface, projecting the reflected sunlight caught by the textured surface. An anti-reflective coating is applied to the rough surface to improve the cell's ability to capture sunlight $[13,14]$. This coating reduces reflection by around $10 \%$. Total reflection is reduced by less than $5 \%$ when texturing and anti-reflective (AR) coating are used together. In this work, we will implement $40^{\circ}$ incident plane and for AR coating, we will utilize Titanium Oxide (TiO) or Polysilicon (poly-Si).
A)
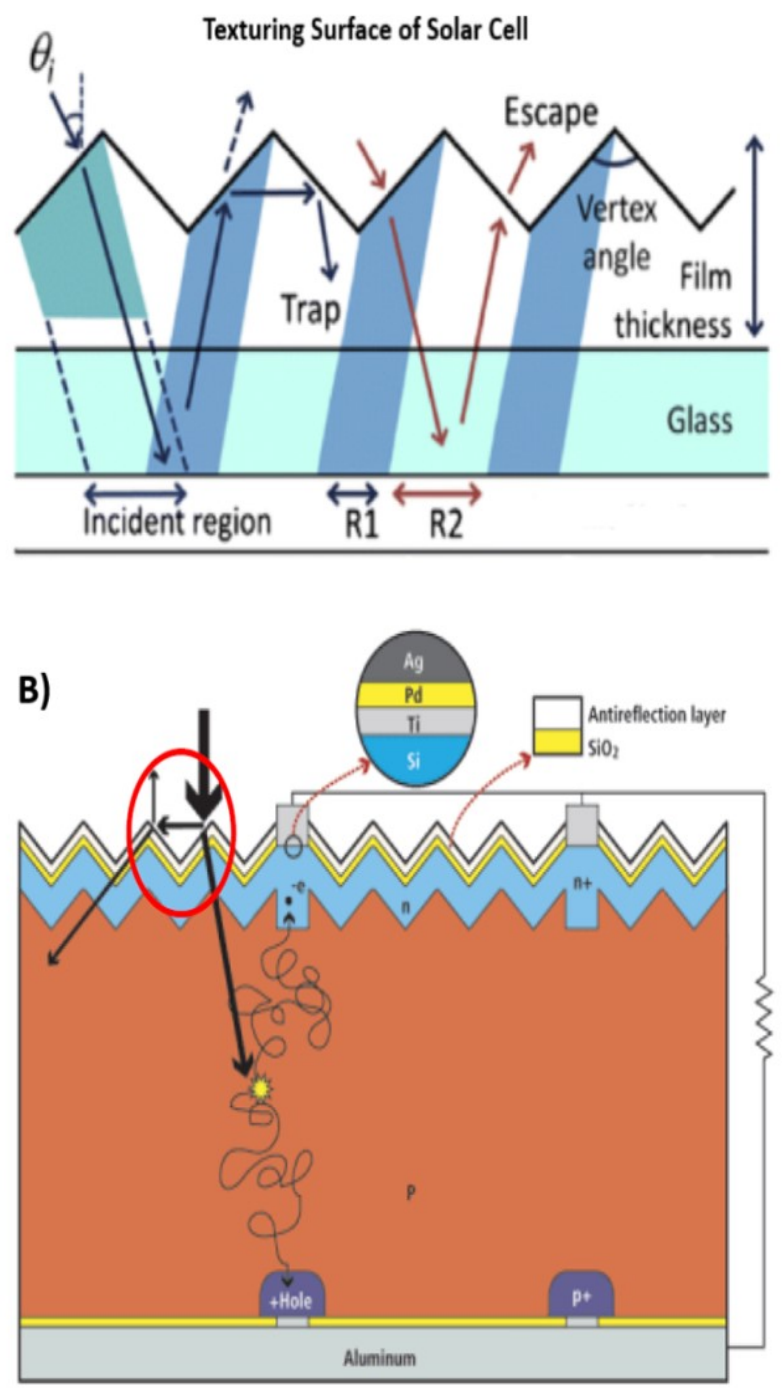

Figure 04: Surface Texturing and AR Coating With $40^{\circ}$ Incident Plane to Capture Reflective Sunlight. Schematic of a Simple Single-Junction Back Contact Solar Cell Structure, Where the Photogeneration of Electron-Hole Pairs Is Exhibited [15,2]

\section{Doping Concentration of Semiconductor and PN Junctions}

The layer beneath the AR coating is created by depositing silicon dioxide to reduce the number of defects at the silicon interface and therefore lower surface recombination velocities, which is a critical metric for a solar cell's efficiency. The following layer is heavily doped with an acceptor material to make it $\mathrm{n}+$, resulting in a Front Surface Field (FSF) that keeps surface recombination velocity below $10 \mathrm{~cm} / \mathrm{s}$, resulting in efficiencies of around $26 \%$ gained in this paper. To produce an 'extended carrier lifetime' for 
improved output efficiency, the bulk region is lightly n-type doped.

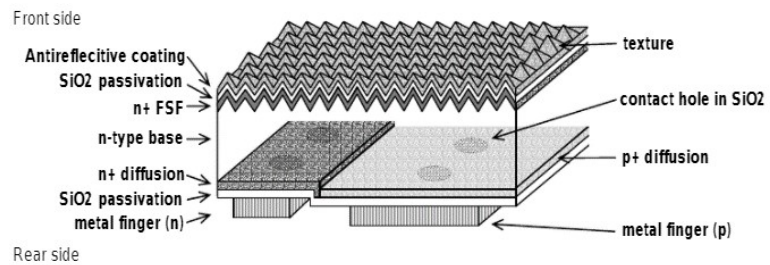

Figure 05: SunPower Corporation's High-Efficiency IBC NType Si Solar Cell with Metallic Conductors at The Back [4]

The bottom layer of the IBC solar cell is substantially doped, with doping concentrations ranging between $10^{18}$ atoms $/ \mathrm{cm}^{3}$ and $10^{20}$ atoms $/ \mathrm{cm}^{3}$ and these regions collect the produced carriers. Because they are more likely to recombine before traversing the cell, the $\mathrm{p}$ region is made larger than the $\mathrm{n}$ region, allowing a shorter path for the hole. A SiO2 layer beneath the $n$ and $p$ regions creates paths through the $\mathrm{n}$ and $\mathrm{p}$ regions to connect the $\mathrm{n}$ and $\mathrm{p}$ regions to the electrodes on the cell's bottom [7,14]. To reduce recombination losses at the interface between the metal contacts and the semiconductor material, the $\mathrm{SiO} 2$ layer provides sunlight reflected back towards the top of the cell. The diagram of the conceptual structure is shown in Figure 05 .

\section{DEVICE FABRICATION AND SIMULATION USING SILVACO TCAD}

\section{A. Defining the Meshed Model and Front Surface Field (FSF) Region}

The Silvaco TCAD device simulation tool was used to develop and simulate a $100 \times 250$ um IBC solar cell in this paper. Devedit is used to define the device's regions and material type, as well as electron and hole lifetimes and surface recombination velocity.

In Devedit, the top $\mathrm{SiO} 2$ layer and $\mathrm{AR}$ coating are deployed (Figure 06-A). The pyramid like surface texturing (red) demonstrating the anti-reflective and enhanced sunlight capturing mechanism. Because the thickness of the $\mathrm{SiO} 2$ layer affects the cell's optical intensity, this model uses a thickness of $5 \mathrm{~nm}$ to allow adequate sunlight into the cell. Both Titanium Oxide (TiO) and Polysilicon have been used separately as the AR coating to investigate the optimum performance of the cell.

The FSF is the next layer, which is made up of doped $n+$ material with a thickness of $0.5 \mathrm{um}$. This region's doping concentration is $10^{15}-10^{17} \mathrm{~cm}^{3}$, resulting in a reasonable balance between open circuit voltage and short circuit current, leading in increased efficiency.
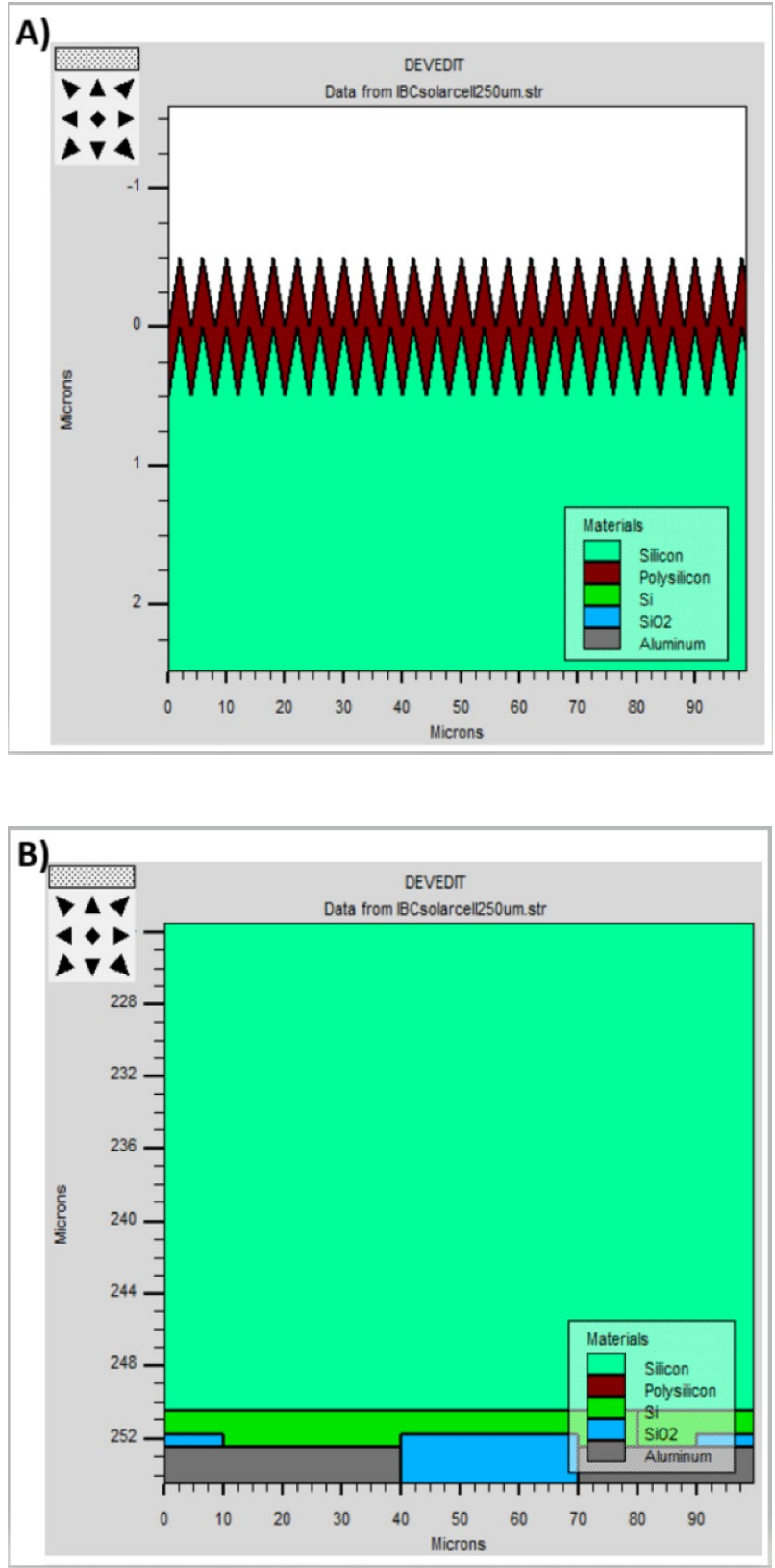

Figure 06: (A) Top View of The Solar Cell with Texturing and Polysilicon AR Coating. (B) Bottom View with Aluminum Electrodes at The Back and Sio2 as Insulator to Prevent Short Circuit

\section{B. Defining Electrodes, Bulk Region and Insulator Layer Between Conductors}

To explore the effect of bulk thickness while taking flexibility into account, the thickness of the bulk region was altered from 50 to $1000 \mathrm{um}$. It is a lightly doped n-type material with a carrier concentration of $10^{15} / \mathrm{cm}^{3}$. The $\mathrm{n}+$ and $\mathrm{p}^{+}$areas near the bottom of the cell had doping concentrations of $5 \times 10^{18}-5 \times 10^{21}$. The $\mathrm{p}+$ and $\mathrm{n}+$ regions have widths of $80 \mathrm{um}$ and $20 \mathrm{um}$, respectively. 
The following layer is a $1 \mathrm{um} \mathrm{SiO} 2$ layer with microscopic 30-20um gaps in it to facilitate contact between the electrodes and the $\mathrm{p}+/ \mathrm{n}+$ regions. Shorting between the electrodes is prevented by the $\mathrm{SiO} 2$. Figure 07 depicts the device's completed structure.
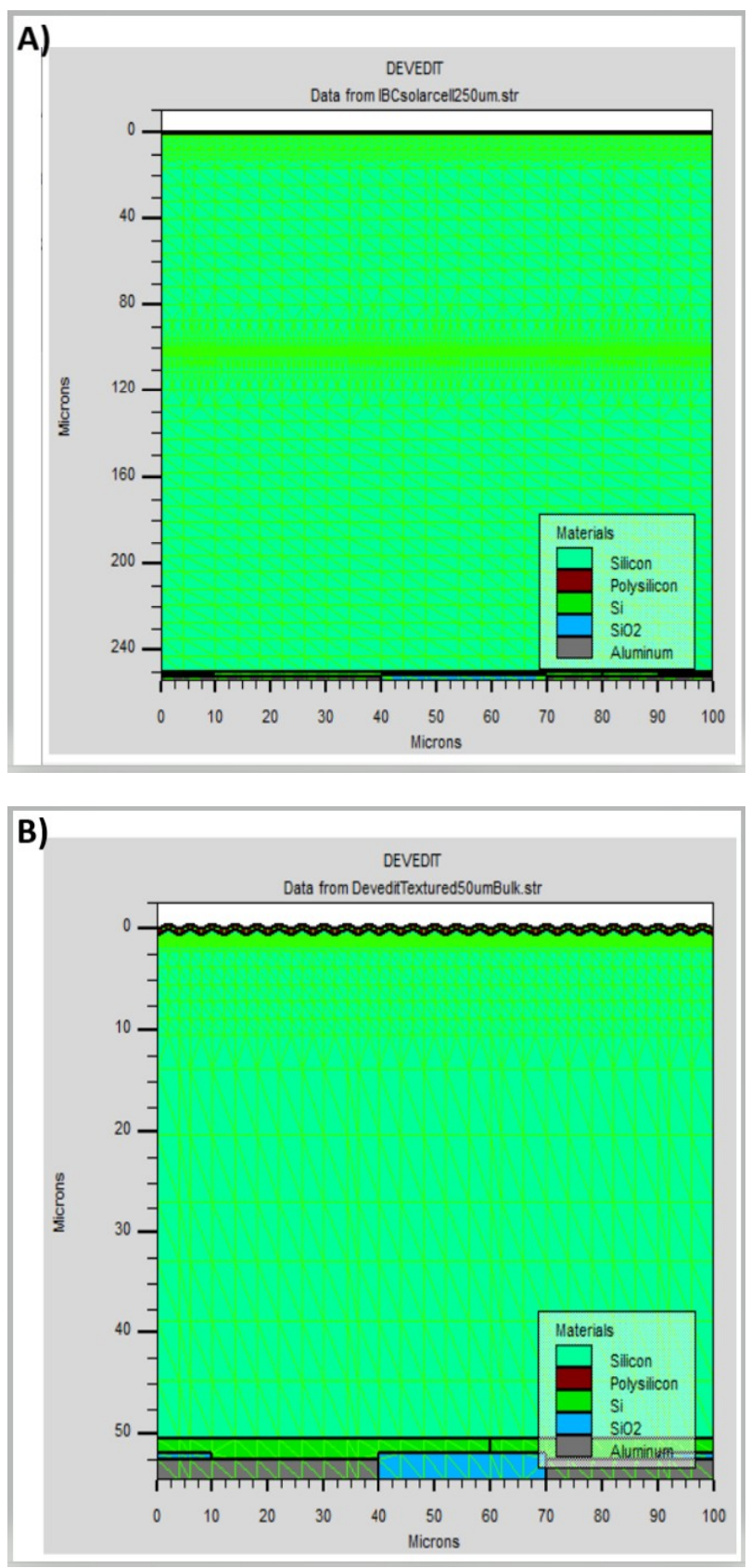

Figure 07: (A) Complete Device Structure with Meshed Model 100x250um Bulk Thickness. (B) For Clear View 100x50um Bulk Thickness

\section{RESULTS AND ANALYSIS}

Atlas is a device simulator based on physical structures and bias settings that predicts electrical characteristics. It operates by applying a set of differential equations to the nodes of a grid placed on a device, based on Maxwell's laws and the semiconductor transport equations.

The three equations derived from Maxwell's laws are Poisson's equation, continuity equations and transport equation [7]. The electrostatic potential is related to the space charge density by Poisson's Equations, which are provided by

$$
\begin{aligned}
& \operatorname{div}(\varepsilon \nabla \Psi)=-\rho \\
& \frac{\partial n}{\partial t}=-\frac{1}{q} \operatorname{div} \vec{J}_{n}+G_{n}-R_{n} \\
& \frac{\partial p}{\partial t}=-\frac{1}{q} \operatorname{div} \vec{J}_{p}+G_{p}-R_{p}
\end{aligned}
$$

The drift-diffusion model (DDM) is created by applying approximations and simplifications of these equations. When nano devices are used, the energy-balance transport model needing DDM must be used. In this thesis, the current density is modelled using the following drift-diffusion model equations $[2,7]$ :

$$
\begin{aligned}
& \vec{J}_{n}=q n \mu_{n} \vec{E}_{n}+q D_{n} \nabla n \\
& \vec{J}_{p}=q p \mu_{p} \vec{E}_{p}-q D_{p} \nabla p
\end{aligned}
$$

We get a model that accounts for current created from a light source by adding an electron generation term and a hole-generation term to the right side of the equation. SILVACO Atlas is used to imitate a solar cell in this way. Atlas must solve equations based on the models chosen to simulate the device. The Newton method is used to solve the entire system of equations in this study. It keeps simulating until it finds a stable solution. To optimize power output, the completed device went through multiple simulations and modifications of the parameters.

\section{A. Investigating Device IV Efficiency Depending on Bulk Thickness}

When comparing solar cells, it's crucial to make sure they're being compared under the same working conditions. Because cell efficiency is affected by temperature, comparing two cells tested at different temperatures is not a good comparison. Similarly, because the test conditions alter the output, it's hard to determine which cell is actually better if two cells are tested using different spectrums or sun concentrations. Therefore, we will test the solar cell keeping temperature and light intensity same and we will only change the bulk thickness to determine the efficiency of the 
solar cell that depends on bulk thickness. The IV curves of the final results for a device with varying bulk thickness are shown in Figure 08:
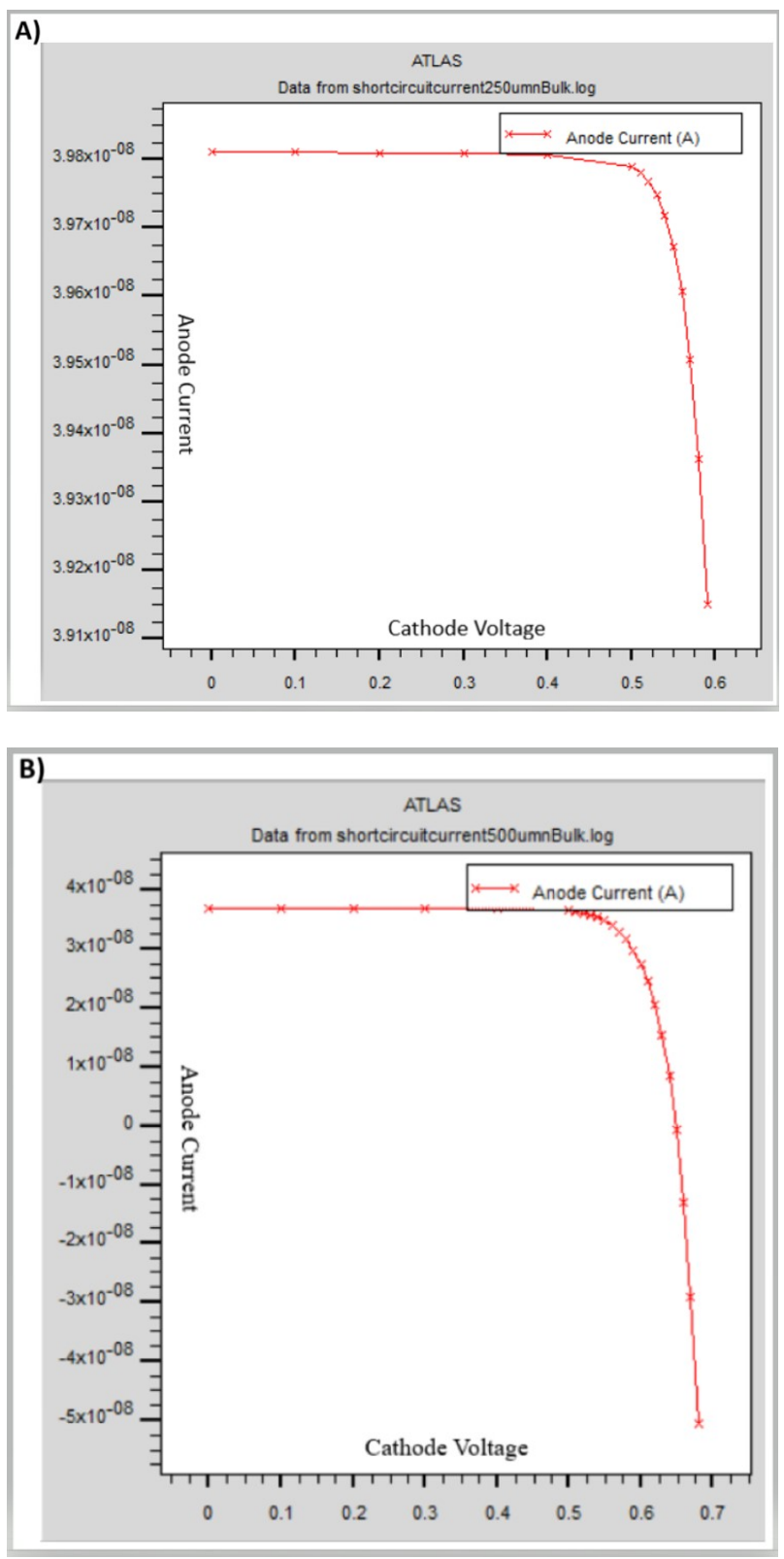

Figure 08: (A) IV Characteristics of IBC Solar Cell with Bulk Thickness 250um (100x250um) (B) IV Characteristics of IBC Solar Cell with Bulk Thickness 250um (100x500um)

The short circuit (SC) current increases in proportion to bulk thickness for the designed IBC cell, as seen in the IV graph above. This bulk region collects sunlight for photosynthesis. If the bulk is too thin, an electron-hole pair is less likely to form, and recombination is more common when the bulk area is wider, resulting in a higher SC current. The influence of bulk thickness on the specified cell is shown in the Table01:
Table 01: Relation Between Bulk Thickness and Short Circuit Current

\begin{tabular}{|c|c|c|c|c|}
\hline $\begin{array}{c}\text { Bulk } \\
\text { Thickness } \\
(\mathrm{uM})\end{array}$ & $\begin{array}{c}\text { Atmospheric } \\
\text { Temperature } \\
(\mathrm{K})\end{array}$ & $\begin{array}{c}\text { Light Beam } \\
\text { Intensity } \\
\left(\text { Watt/Cm }{ }^{2}\right)\end{array}$ & $\begin{array}{c}\text { Open } \\
\text { Circuit } \\
\text { Voltage } \\
(\mathrm{mV})\end{array}$ & $\begin{array}{c}\text { Short } \\
\text { Circuit } \\
\text { Current } \\
(\mathrm{uA})\end{array}$ \\
\hline 50 & 298 & 1 & 680 & 0.03819 \\
\hline 100 & 298 & 1 & 680 & 0.04037 \\
\hline 150 & 298 & 1 & 680 & 0.04145 \\
\hline 200 & 298 & 1 & 680 & 0.04207 \\
\hline 250 & 298 & 1 & 680 & 0.04217 \\
\hline 300 & 298 & 1 & 680 & 0.04400 \\
\hline 350 & 298 & 1 & 680 & 0.04662 \\
\hline 400 & 298 & 1 & 680 & 0.04869 \\
\hline 450 & 298 & 1 & 680 & 0.04880 \\
\hline 500 & 298 & 1 & 680 & 0.05062 \\
\hline 550 & 298 & 1 & 680 & 0.05240 \\
\hline 650 & 298 & 1 & 680 & 0.05585 \\
\hline 750 & 298 & 1 & 680 & 0.05905 \\
\hline 850 & 298 & 1 & 680 & 0.06107 \\
\hline 1000 & 298 & 1 & 680 & 0.06506 \\
\hline
\end{tabular}

A closer examination of the IV curve (Figure 09) reveals that $\mathrm{Voc}=680.0 \mathrm{mV}$ and $\mathrm{Isc}=0.04037 \mathrm{uA}$ for a $100 \times 100 \mathrm{um}$ IBC solar cell. The SC current increases as the bulk thickness increases. The SC current for a $100 \times 1000 u m$ cell is $0.06506 \mathrm{uA}$, which is very good; however, due to the 1000 um bulk thickness, the cell is not flexible and is not adaptable to a wide range of applications. The SC current drops by nearly $0.01444 \mathrm{uA}$ after a 500um reduction. However, the 500um cell is still not considered flexible; according to recent studies, solar cells with a thickness of less than 270um are considered flexible [2]. The SC current decreases by nearly $0.022 \mathrm{uA}$ as the bulk thickness is reduced to $250 \mathrm{um}$. However, considering the flexibility, durability and economic advantages of thin solar cell, the designed 100x250um IBC solar device with $0.04217 \mathrm{uA} \mathrm{SC}$ current is promising.

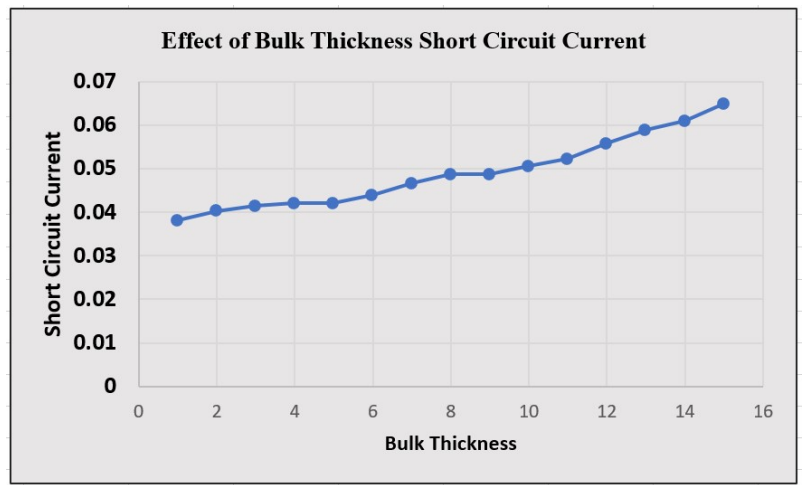

Figure 09: Graphical View of The Relation Between Short Circuit Current and Bulk Thickness to Analyze the Stability

\section{B. Effect of Light Intensity on The IBC Solar Cell (250 um Bulk Thickness)}

The Luminous Tool is used in this paper to investigate the effect of light intensity on the designed IBC solar cell. Luminous is a SILVACO-Atlas-integrated general-purpose software for light propagation and absorption. Luminous 
computes the optical intensity within a device and uses it to determine the photo-generation rates used in the solution equations. Luminous can also simulate a complicated AR coating structure to a device; for this device, polysilicon is used as the AR coating, which is investigated with the help of the Luminous Tool [17]. The data in the Table-02, shows that SC current increases with increasing light intensity.

Table 02: Effect of Light Intensity on The Designed IBC Solar Cell

\begin{tabular}{|c|c|c|c|c|c|}
\hline $\begin{array}{c}\text { Bulk } \\
\text { Thickne } \\
\text { ss }(\mu \mathrm{m})\end{array}$ & $\begin{array}{c}\text { Atmosp } \\
\text { here } \\
\text { Tempera } \\
\text { ture (K) }\end{array}$ & $\begin{array}{c}\text { Light } \\
\text { Beam } \\
\text { Intensit } \\
\mathrm{y} \\
(\mathrm{watt} / \mathrm{c} \\
\left.\mathrm{m}^{2}\right)\end{array}$ & $\begin{array}{c}\text { Open } \\
\text { circuit } \\
\text { voltag } \\
\text { e }(\mathrm{mV})\end{array}$ & $\begin{array}{c}\text { Short } \\
\text { circuit } \\
\text { current } \\
(\mathrm{uA})\end{array}$ & $\begin{array}{c}\text { Short } \\
\text { circuit } \\
\text { current } \\
(\mathrm{uA})\end{array}$ \\
\cline { 4 - 6 } & & 0 & $\begin{array}{c}\text { Polysilicon } \\
\text { AR } \\
\text { Coating }\end{array}$ & $\begin{array}{c}\text { TiO AR } \\
\text { Coating }\end{array}$ \\
\hline 250 & 298 & 0 & 680 & 0.04050 & 0.95146 \\
\hline 250 & 298 & 1 & 680 & 0.04217 & 0.95292 \\
\hline 250 & 298 & 10 & 680 & 0.39722 & 0.97280 \\
\hline 250 & 298 & 20 & 680 & 0.75219 & 1.14570 \\
\hline 250 & 298 & 50 & 680 & 1.75485 & 1.90772 \\
\hline 250 & 298 & 100 & 680 & 3.25510 & 3.67873 \\
\hline
\end{tabular}

The data demonstrate that the designed device is very light efficient producing higher short circuit current with increase in light intensity. For a light intensity of $10 \mathrm{watt} / \mathrm{cm}^{2}$, the SC current increases drastically from $0.04217 \mu \mathrm{A}$ to $0.39722 \mu \mathrm{A}$ (Figure 10). This behavior of the cell prove that the device will perform very efficiently in a sunny day. Furthermore, there is a SC current of $0.04050 \mathrm{uA}$ at zero light intensity meaning that on the normal days even if the sunlight is not very intense, the cell still produces good output. The data also suggests that $\mathrm{TiO}$ coating is better than polysilicon coating because $\mathrm{TiO}$ reduces reflection of sunlight more effectively than polysilicon providing higher SC Current. However, due to the conventional practice, polysilicon AR coating has been carried out in this paper.

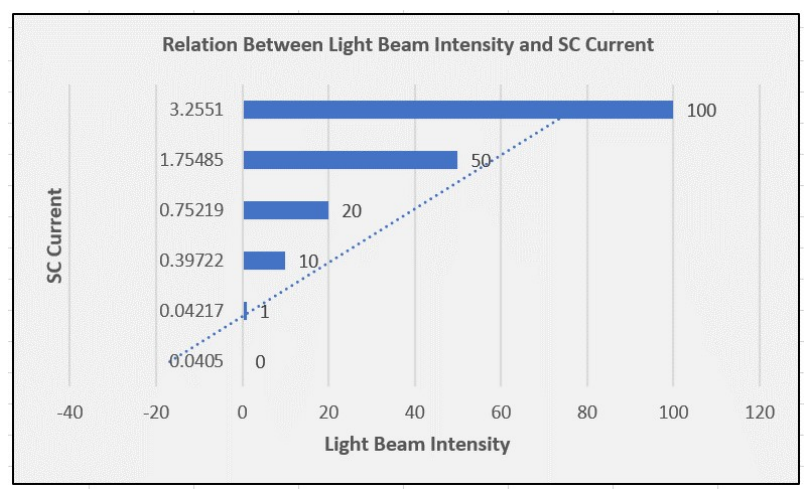

Figure 10: Graphical View of The Relation Between Light Beam Intensity and SC Current

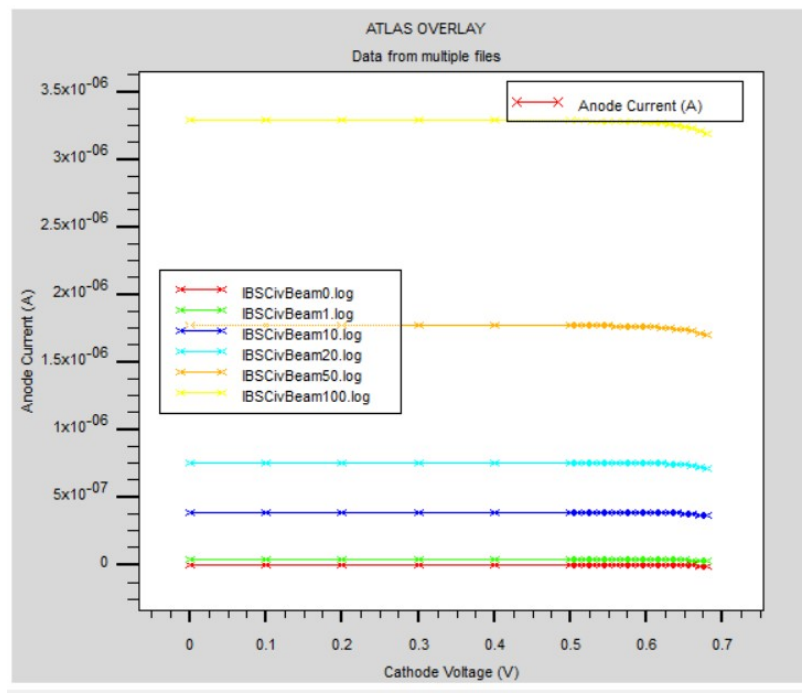

Figure 11: IV Characteristics Depending on The Relation Between Light Beam Intensity and SC Current

\section{Effect of Atmospheric Temperature on The IBC Solar Cell (250 Um Bulk Thickness)}

Simulations are first carried out at room temperature $\left(25^{\circ} \mathrm{C}\right)$ which is the 'preferred temperature' to test solar cell performance [18] implementing monochromatic light of lum and optical power densities of 1,10 , and $100 \mu \mathrm{m} / \mathrm{cm}^{2}$. The photocurrent was discovered to rise with the intensity of light. To investigate the temperature effect, simulations were run on the identical IBC solar cell at temperatures ranging from 0 to 50 degrees Celsius. Result showed that when the temperature rises, the leakage current rises, lowering the SC current. Temperature decreases the band gap of the semiconductor, altering most of the semiconductor material's properties.

When the band gap of a semiconductor narrows as the temperature rises, the energy of electrons in the material rises. The bond can be broken with less energy. In a bond model of a semiconductor band gap, lowering the bond energy lowers the band gap. As a result, raising the temperature lowers the band gap. The equation for the total current in a solar cell is $[7,18]$ :

$$
I=I o\left[e^{\frac{e V}{k T}}-1\right]-I p
$$

where $\mathrm{Io}=$ reverse saturation current and $\mathrm{Eg}(\mathrm{eV})$ is the band-gap energy $=h \vartheta$

When the temperature rises, thermal ionization causes electrons and holes to separate, resulting in leakage current and a decrease in SC current. The data in Table 03 depicts the effect of atmospheric temperature on the IBC Solar cell designed.

Table 03: Effect of Temperature on The IBC Solar Cell Output (Open Circuit Voltage Is Set To 0.680V) 


\begin{tabular}{|c|c|c|c|c|c|}
\hline $\begin{array}{c}\text { Bulk } \\
\text { thickness }\end{array}$ & $\begin{array}{l}\text { Open } \\
\text { circuit }\end{array}$ & \multicolumn{2}{|c|}{$\begin{array}{l}\text { Atmosphere } \\
\text { Temperature }\end{array}$} & \multirow{2}{*}{$\begin{array}{c}\begin{array}{c}\text { Light } \\
\text { Beam } \\
\text { Intensity } \\
\left(\text { watt } / \mathrm{cm}^{2} \text { ) }\right.\end{array} \\
10\end{array}$} & \multirow{2}{*}{$\begin{array}{c}\begin{array}{c}\text { Short } \\
\text { circuit } \\
\text { current } \\
\text { (uA) }\end{array} \\
0.39722\end{array}$} \\
\hline 250 & 680 & $273 \mathrm{~K}$ & $0^{\circ} \mathrm{C}$ & & \\
\hline 250 & 680 & $288 \mathrm{~K}$ & $15^{\circ} \mathrm{C}$ & 10 & 0.38778 \\
\hline 250 & 680 & $293 \mathrm{~K}$ & $20^{\circ} \mathrm{C}$ & 10 & 0.38755 \\
\hline 250 & 680 & $298 \mathrm{~K}$ & $25^{\circ} \mathrm{C}$ & 10 & 0.38731 \\
\hline 250 & 680 & $303 \mathrm{~K}$ & $30^{\circ} \mathrm{C}$ & 10 & 0.38708 \\
\hline 250 & 680 & $308 \mathrm{~K}$ & $35^{\circ} \mathrm{C}$ & 10 & 0.38685 \\
\hline 250 & 680 & $323 \mathrm{~K}$ & $50^{\circ} \mathrm{C}$ & 10 & 0.38617 \\
\hline
\end{tabular}

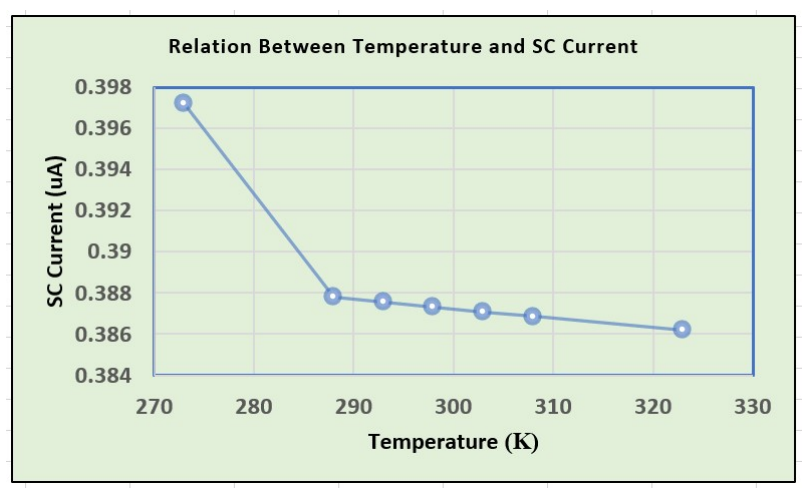

Figure 12: Graphical View of The Relation Between Atmospheric Temperature and SC Current

Analyzing the above experimental data and graphical relationship, it can be concluded that the designed IBC cell performing very efficiently at $0^{\circ} \mathrm{C}$ temperature, however with the increase in temperature the IV curve falls gradually. The IV curve shows that, from $288 \mathrm{~K}\left(15^{\circ} \mathrm{C}\right)$ temperature the curve remains quite stable until the temperature reaches to $323 \mathrm{~K}\left(50^{\circ} \mathrm{C}\right)$ with very slight drops in SC current. At $298 \mathrm{~K}$ $\left(25^{\circ} \mathrm{C}\right)$ the cell provides SC current of $0.38731 \mathrm{uA}$. These characteristics proves that, the designed solar cell performs efficiently even in higher atmospheric temperature which demonstrates the device is temperature efficient.

\section{Analysis of Fill Factor and Efficiency of The Designed IBC Cell}

When analyzing the performance of solar cells and their output, there are a number of variables to consider. The open circuit voltage (Voc) and short circuit current (Isc) are two variables that show the cell's maximum voltage and current output and serve as principal indicator of its performance. Fill factor (FF), which is a measurement of how nearly a solar cell behaves like an ideal source, is a better indicator. A standard value of $\mathrm{FF}$ is approximately $80 \%$ [17].

The most significant parameter is efficiency, which is the most accurate predictor of performance because it connects the power input and output. Higher efficiency corresponds to a better cell. As a result, the experimental data in Table04, which include FF and efficiency, illustrate the cell's ultimate performance analysis in this study.

Table 04: Summary of Device Performance and Efficiency (Cell Active Area $=100 \mathrm{~cm}^{2}$, Atmospheric Temperature $=25^{\circ} \mathrm{C}$, Aperture Width 10/20, Light Intensity $=1$ watt $/ \mathrm{cm} 2$ )

\begin{tabular}{|c|c|c|c|c|c|c|}
\hline $\begin{array}{c}\text { Bulk } \\
\text { Thickness }\end{array}$ & $\begin{array}{c}\text { Open } \\
\text { circuit } \\
\text { voltage } \\
\text { (mV) }\end{array}$ & $\begin{array}{c}\text { Short } \\
\text { circuit } \\
\text { current } \\
\text { (uA) }\end{array}$ & $\begin{array}{c}\text { Maximum } \\
\text { Power } \\
(\mathrm{mW})\end{array}$ & $\begin{array}{c}\text { Short circuit } \\
\text { current } \\
\text { density } \\
\text { (mA/cm2) }\end{array}$ & $\begin{array}{c}\text { Fill } \\
\text { Factor, } \\
\text { FF (\%) }\end{array}$ & $\begin{array}{c}\text { Efficiency } \\
(\%)\end{array}$ \\
\hline $\mathbf{5 0}$ & $\mathbf{6 8 0}$ & $\mathbf{0 . 0 3 8 1 9}$ & $\mathbf{0 . 0 2 0 9 6}$ & $\mathbf{3 8 . 1 9 5 2}$ & $\mathbf{8 0 . 1 0}$ & $\mathbf{2 5 . 0 6}$ \\
\hline $\mathbf{1 5 0}$ & $\mathbf{6 8 0}$ & $\mathbf{0 . 0 4 1 4 5}$ & $\mathbf{0 . 0 2 1 8 0}$ & $\mathbf{4 0 . 3 7 8 1}$ & $\mathbf{7 9 . 4 0}$ & $\mathbf{2 6 . 0 7}$ \\
\hline $\mathbf{2 5 0}$ & $\mathbf{6 8 0}$ & $\mathbf{0 . 0 4 2 1 7}$ & $\mathbf{0 . 0 2 1 1 5}$ & $\mathbf{4 2 . 1 7 1 6}$ & $\mathbf{7 3 . 7 7}$ & $\mathbf{2 5 . 2 9}$ \\
\hline 400 & 680 & 0.04869 & 0.01993 & 48.6975 & 60.19 & 23.83 \\
\hline 500 & 680 & 0.05062 & 0.19165 & 50.6243 & 55.67 & 22.91 \\
\hline 650 & 680 & 0.05585 & 0.01787 & 55.8570 & 47.05 & 21.37 \\
\hline 750 & 680 & 0.05905 & 0.01702 & 59.0539 & 42.39 & 20.35 \\
\hline 850 & 680 & 0.06107 & 0.01622 & 60.8501 & 39.20 & 19.40 \\
\hline 1000 & 680 & 0.06506 & 0.01499 & 65.0606 & 33.88 & 17.92 \\
\hline
\end{tabular}

In the following table, we will investigate the optimum performance of the designed IBC Solar cell changing atmospheric temperature to $15^{\circ} \mathrm{C}$ because at this condition solar cell gives its peak efficiency [18]. The experiment will demonstrate the average performance of the designed device in optimum condition. 
Table 05: Summary of Device Performance and Efficiency $\left(\right.$ Cell Active Area $=100 \mathrm{~cm}^{2}$, Atmospheric Temperature $=15^{\circ} \mathrm{C}$, Aperture Width 10/20, Light Intensity $=1$ watt $/ \mathrm{cm} 2$ )

\begin{tabular}{|c|c|c|c|c|c|c|}
\hline $\begin{array}{c}\text { Bulk } \\
\text { Thickness }\end{array}$ & $\begin{array}{c}\text { Open } \\
\text { circuit } \\
\text { voltage } \\
(\mathrm{mV})\end{array}$ & $\begin{array}{c}\text { Short } \\
\text { circuit } \\
\text { current } \\
(\mathrm{uA})\end{array}$ & $\begin{array}{c}\text { Maximum } \\
\text { Power } \\
(\mathrm{mW})\end{array}$ & $\begin{array}{c}\text { Short circuit } \\
\text { current } \\
\text { density } \\
(\mathrm{mA} / \mathrm{cm} 2)\end{array}$ & $\begin{array}{c}\text { Fill } \\
\text { Factor, FF } \\
(\%)\end{array}$ & $\begin{array}{c}\text { Efficiency } \\
(\%)\end{array}$ \\
\hline $\mathbf{5 0}$ & $\mathbf{6 8 0}$ & $\mathbf{0 . 0 3 8 2 5}$ & $\mathbf{0 . 0 2 3 1 1}$ & $\mathbf{3 8 . 2 0 1 6}$ & $\mathbf{8 8 . 9 7}$ & $\mathbf{2 7 . 6 4}$ \\
\hline $\mathbf{1 5 0}$ & $\mathbf{6 8 0}$ & $\mathbf{0 . 0 4 1 7 2}$ & $\mathbf{0 . 0 2 4 0 9}$ & $\mathbf{4 0 . 4 0 5 2}$ & $\mathbf{8 7 . 6 8}$ & $\mathbf{2 8 . 8 1}$ \\
\hline $\mathbf{2 5 0}$ & $\mathbf{6 8 0}$ & $\mathbf{0 . 0 4 3 0 5}$ & $\mathbf{0 . 0 2 3 4 5}$ & $\mathbf{4 3 . 1 5 1 3}$ & $\mathbf{8 6 . 6 3}$ & $\mathbf{2 8 . 0 4}$ \\
\hline 400 & 680 & 0.04901 & 0.02221 & 49.1247 & 85.44 & 26.56 \\
\hline 500 & 680 & 0.05103 & 0.02140 & 51.9547 & 84.86 & 25.55 \\
\hline
\end{tabular}

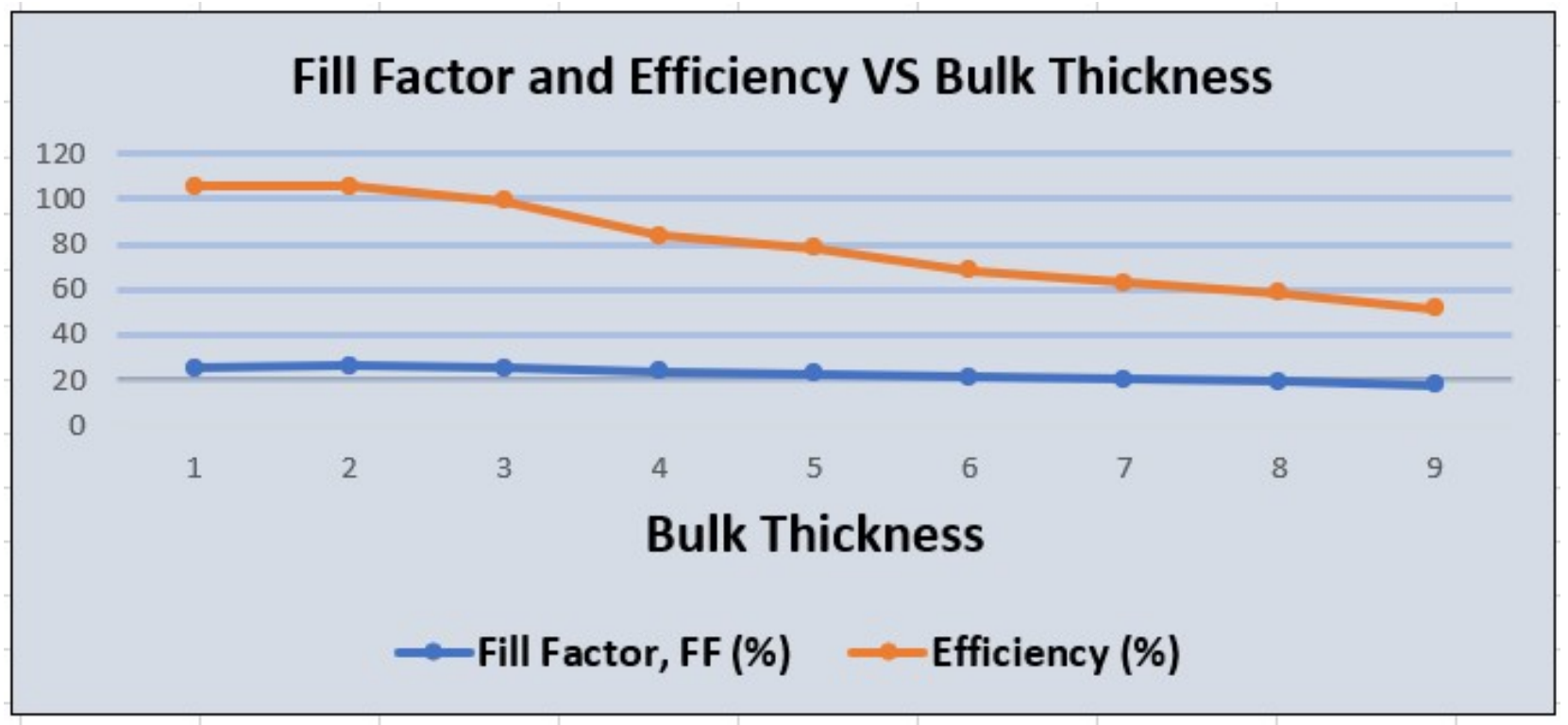

Figure 13: Graphical View of Fill Factor and Efficiency vs Bulk Thickness

Analyzing the above data, it can be concluded that, the IBC solar device with $100 \times 150$ um parameters provides the best efficiency which is approximately $26.07 \%$ with a fill factor of about $80 \%$. The cell with our default parameter $100 \times 250$ um dimension has also provided promising performance with $25.29 \%$ efficiency and $73.77 \%$ fill factor rate.

Another remarkable observation is the relation between bulk thickness and efficiency. The short circuit current increases in proportion with bulk thickness, however with material thickness increased, it absorbs more incident radiation as the incident photons decay exponentially with the distance traveled in the bulk region. As the thickness of the bulk region increases the recombination loss increases. If the travelling distance gets larger than the diffusion length it will result in higher FF due to the decrease in sheet resistance of the active layer but this phenomenon lowers the efficiency $[7,20]$.

Therefore, the selection of bulk thickness is very important. In this work, the data shows very promising results for
$100 \times 50$ um to $100 \times 250$ um dimensional IBC solar cell where the bulk thickness varies from 50um to $250 \mathrm{um}$. The IBC cell with only 50um bulk thickness has an efficiency of $25.06 \%$ with a fill factor of $80.10 \%$, which demonstrates excellent device performance while promising for thin structure.

The optimum performance of the device has been recorded in Table05 which again shows that the device with $100 \times 150$ um has the highest efficiency of $28.81 \%$ with an FF of $87.68 \%$ followed by $100 \times 250 u$ device performance. The 50umm bulk thickness device has the highest FF rate which means this device performs most ideally and the $27.64 \%$ efficiency implies that ultra-thin cell performance is achievable.

\section{E. Comparison of Device Performance with Recent Interdigitated Back Contact Solar Cells}

In this section we will make compare our device performance with similar interdigitated back contact solar cell designed by researchers recently. We will consider the four principal parameters of performance analyzers which 
are open circuit voltage (Voc), Short circuit current density (Jsc), Fill Factor (FF) and Efficiency. Most optimum performances for each device have been taken into account in this comparison.

Table 06: Comparison of Device Performance with Recent Interdigitated Back Contact Solar Cell

\begin{tabular}{|c|c|c|c|c|c|}
\hline Papers & $\begin{array}{l}\text { Nadjat Benadla } \\
\text { et al [21] }\end{array}$ & $\begin{array}{c}\text { Weiliang Wu et } \\
\text { al [3] } \\
\text { [doi.org/10.1063 }\end{array}$ & $\begin{array}{l}\text { S. Schäfera et al [16] } \\
\text { [doi.org/10.1016/j.sol }\end{array}$ & $\begin{array}{c}\text { Morris Dahlinger et } \\
\text { al [22] } \\
\text { [DOI: }\end{array}$ & $\begin{array}{c}\text { Proposed IBC } \\
\text { Solar Cell }\end{array}$ \\
\hline $\begin{array}{l}\text { Performance } \\
\text { Parameters }\end{array}$ & $\begin{array}{c}\text { [DOI: } \\
\text { 10.11591/ijece. } \\
\text { v9i6.pp4566- } \\
\text { 4572] }\end{array}$ & $/ 1.5049288]$ & mat.2019.110021] & $\begin{array}{c}\text { 10.1016/j.egypro. } 201 \\
3.07 .274]\end{array}$ & \\
\hline $\begin{array}{l}\text { Open circuit } \\
\text { voltage }(\mathrm{mV})\end{array}$ & 635 & 709 & 700 & 669 & 680 \\
\hline $\begin{array}{l}\text { Short circuit } \\
\text { current density } \\
(\mathrm{mA} / \mathrm{cm} 2)\end{array}$ & 39.20 & 41.50 & 42.50 & 41.30 & 40.40 \\
\hline $\begin{array}{c}\text { Fill Factor, FF } \\
(\%)\end{array}$ & 77.70 & 75.60 & 80.70 & 79.80 & 87.68 \\
\hline Efficiency (\%) & 20.19 & 22.20 & 26.00 & 22.20 & 28.81 \\
\hline
\end{tabular}

\section{CONCLUSION}

In this paper, an interdigitated back-surface-contact solar cell was modeled using SILVACO TCAD software following the SunPower A-300 device structure, with active cell area of $100 \mathrm{~cm}^{2}$. The designed device went through a number of different modifications of parameters to analyze the performance. The effect of bulk thickness on efficiency has been explored where the thickness varying from 50um to $1000 \mathrm{um}$. The data suggested that, with the increase of bulk thickness the SC current increases, however due to the recombination loss and diffusion length, the efficiency decreases. The cell with dimensions of $100 \times 50,100 \times 150$ and $100 x 250$ um provide maximum efficiency of $27.64-$ $28.81 \%$ with excellent Fill Factor of about $87-89 \%$ suggesting for successful very thin, flexible and durable IBC solar cell. Effect of light intensity with $0,1,10,20,50$ and 100 watt $/ \mathrm{cm}^{2}$ has been investigated using Luminous tool in SILVACO and the results demonstrate that the cell performs efficiently even in a normal day with $1 \mathrm{watt} / \mathrm{cm}^{2}$ light intensity. The data also imply that with the increase in light intensity as in sunny days the SC current increases drastically indicating light efficient IBC cell. The final investigation on atmospheric temperature, is a very important factor to analyze the performance of the solar cell. The leakage current increases in proportion to temperature resulting in reduction of short circuit current. The data implies that when the temperature increases from $0^{\circ} \mathrm{C}$ to nearly $15^{\circ} \mathrm{C}$, it affects the SC current by dropping $0.009 \mathrm{uA}$, however after that the SC current remains stable despite any increase in temperature, this characteristic demonstrate that the designed IBC solar cell is a promising temperature efficient device which maintains its efficiency even up to $50^{\circ} \mathrm{C}$.

\section{REFERENCES}

[1]. Chan, C., Hallam, B. and Wenham, S., 2012. Simplified Interdigitated Back Contact Solar Cells. Energy Procedia, 27, pp.543-548.

[2]. S. Green, "Interdigitated back-surface-contact solar cell modeling using Silvaco Atlas", Dudley Knox Library, 2015. Available: http://hdl.handle.net/10945/45861.

[3]. W. Wu et al., "22\% efficient dopant-free interdigitated back contact silicon solar cells", 2018. Available: 10.1063/1.5049288.

[4]. Song, D., Xiong, J., Hu, Z., Li, G., Wang, H., An, H., Yu, B., Grenko, B., Borden, K., Sauer, K., Roessler, T., Cui, J., Wang, H., Bultman, J., Vlooswijk, A. and Venema, P., 2012. Progress in n-type Si solar cell and module technology for high efficiency and low cost. 2012 38th IEEE Photovoltaic Specialists Conference.

[5]. Green, M. A., Emery, K., Hishikawa, Y., Warta, W., Dunlop, E. D., Levi, D. H. and Ho-Baillie, A. W. Y. (2017). Solar cell efficiency tables (version 49). Progress in Photovoltaics: Research and Applications.

[6]. Azo Materials, Buehler, Illinois, United States. 2011. Sample Preparation and Microstructural Analysis of Solar Cells. Available at: https://www.azom.com/article.aspx?ArticleID $=5768$.

[7]. C. Battaglia, A. Cuevasb and S. De Wolfc, "Highefficiency crystalline silicon solar cells: status and perspectives", Energy and Environmental Science, 2016 .

Available: https://pubs.rsc.org/en/content/articlelanding/2016/ee/c 5ee03380b.

[8]. C. Hussain, "Handbook of Nanomaterials for Industrial Applications", Chapter 41 - Engineered Nanomaterials for Energy Applications, Pages 751-767, 2018. Available: https://doi.org/10.1016/B978-0-12-8133514.00043-2.

[9]. "Solar Cell working principle | How solar cell works", $R F \quad$ Wireless World, 2021. Available: 
https://www.rfwireless-world.com/Articles/Solar-Cell-

[10]. R. Jeyakumar et al., "High-efficiency c-Si based interdigitated point contact back heterojunction solar cells", Journal of Materials Science: Materials in Electronics, vol. 28, no. 13, pp. 9697-9703, 2017. Available: 10.1007/s10854-017-6720-1.

[11]. Mat Desa, M., Sapeai, S., Azhari, A., Sopian, K., Sulaiman, M., Amin, N. and Zaidi, S., 2016. Silicon back contact solar cell configuration: A pathway towards higher efficiency. Renewable and Sustainable Energy Reviews, 60, pp.1516-1532.

[12]. N. Guerra, M. Guevara, C. Palacios and F. Crupi, "Operation and physics of photovoltaic solar cells: an overview", I+D Tecnológico, vol. 14, no. 2, pp. 84-95, 2018. Available: 10.33412/idt.v14.2.2077.

[13]. M. Kim, J. Lee and M. Kwak, "Review: Surface Texturing Methods for Solar Cell Efficiency Enhancement", International Journal of Precision Engineering and Manufacturing, vol. 21, no. 7, pp. 1389-1398, 2020. Available: 10.1007/s12541-02000337-5.

[14]. T. M. Letcher and V. M. Fthenakis, "Photovoltaics: The Basics. A Comprehensive Guide to Solar Energy Systems", 2018 Available: https://doi.org/10.1016/B978-0-12-811479-7.00008-7.

[15]. S. Iftiquar and J. Yi, "Numerical simulation and light trapping in perovskite solar cell", Journal of Photonics for Energy, vol. 6, no. 2, p. 025507, 2016. Available: 10.1117/1.jpe.6.025507.

[16]. Schäfer, S., Haase, F., Hollemann, C., Hensen, J., Krügener, J., Brendel, R. and Peibst, R., 2019. 26\%efficient and $2 \mathrm{~cm}$ narrow interdigitated back contact silicon solar cells with passivated slits on two
as-Renewable-Energy-Source.html. edges. Solar Energy Materials and Solar Cells, 200, p.110021.

[17]. M. Dar and S. Ahmed, "Effect of light and heavy ion irradiation on graphene device matrix: Optical and Transport Characteristics", Radiation Physics and Chemistry, vol. 156, pp. 67-72, 2019. Available: 10.1016/j.radphyschem.2018.09.027.

[18]. Honsberg, C. and Bowden, S., 2021. Effect of Temperature | PVEducation. Pveducation.org. Available https://www.pveducation.org/pvcdrom/solar-celloperation/effect-of-temperature.

[19]. B. Solar, "How Temperature \& Shade Affect Solar Panel Efficiency | Boston Solar", Bostonsolar.us, 2021. Available: https://www.bostonsolar.us/solar-blogresource-center/blog/how-do-temperature-and-shadeaffect-solar-panel-efficiency/.

[20]. A. Abdelnaby Zekry, "Advanced solar cell materials and solar cells analytical modeling", 2017. Available: 10.13140/RG.2.2.26299.31527.

[21]. N. Benadla and K. Ghaffour, "Optimizing the performance of photovoltaic cells IBC (contact back interdigitated) by numerical simulation", International Journal of Electrical and Computer Engineering (IJECE), vol. 9, no. 6, p. 4566, 2019. Available: 10.11591/ijece.v9i6.pp4566-4572.

[22]. M. Dahlinger, B. Bazer-Bachi, T. Röder, J. Köhler, R. Zapf-Gottwick and J. Werner, "22.0\% Efficient Laser Doped back Contact Solar Cells", Energy Procedia, vol. 38, pp. 250-253, 2013. Available: 10.1016/j.egypro.2013.07.274. 